\title{
Evaluating the Combined Efficacy of Polymers with Fungicides for Protection of Museum Textiles against Fungal Deterioration in Egypt
}

\author{
OMAR ABDEL-KAREEM* \\ Conservation Department, Faculty of Archaeology, Cairo University, Egypt \\ Received 8 April 2010, revised 19 October 2010, accepted 2 November 2010
}

\begin{abstract}
Fungal deterioration is one of the highest risk factors for damage of historical textile objects in Egypt. This paper represents both a study case about the fungal microflora deteriorating historical textiles in the Egyptian Museum and the Coptic museum in Cairo, and evaluation of the efficacy of several combinations of polymers with fungicides for the reinforcement of textiles and their prevention against fungal deterioration. Both cotton swab technique and biodeteriorated textile part technique were used for isolation of fungi from historical textile objects. The plate method with the manual key was used for identification of fungi. The results show that the most dominant fungi isolated from the tested textile samples belong to Alternaria, Aspergillus, Chaetomium, Penicillium and Trichoderma species. Microbiological testing was used for evaluating the usefulness of the suggested conservation materials (polymers combined with fungicides) in prevention of the fungal deterioration of ancient Egyptian textiles. Textile samples were treated with 4 selected polymers combined with two selected fungicides. Untreated and treated textile samples were deteriorated by 3 selected active fungal strains isolated from ancient Egyptian textiles. This study reports that most of the tested polymers combined with the tested fungicides prevented the fungal deterioration of textiles. Treatment of ancient textiles by suggested polymers combined with the suggested fungicides not only reinforces these textiles, but also prevents fungal deterioration and increases the durability of these textiles. The tested polymers without fungicides reduce the fungal deterioration of textiles but do not prevent it completely.
\end{abstract}

Key words: Egyptian and Coptic Museums in Cairo, fungal deterioration, fungicides with polymers, historical textiles

\section{Introduction}

Fungal deterioration seems to be a predominant feature in museums and other culture objects of organic materials such as paper, textiles, wood, etc. (AbdelKareem et al., 1997; Agrawal, 2001; Bhatnagar and Mani, 2001). The ability of textiles to absorb and retain moisture from the surrounding environment in the museums, coupled with their organic components makes them highly susceptible to fungal deterioration. There are many factors which cause that historical textiles are more liable to fungal deterioration. Textile materials are good nutrient materials for fungi. Progressive changes of the properties of textile materials most commonly happen during natural aging. These changes in the characterization of textile materials cause that historical objects become more susceptible to fungal deterioration (Szostak-Kotowa, 2004).

Fungal deterioration of historical textiles is a serious problem in Egypt (Abdel-Kareem et al., 1997). This is due to the fact that improper environmental conditions in Egypt promote the fungal growth and the nature of the textiles too. Historical textiles in Egypt are more acidic according to the surrounding environments (Abdel-Kareem, 2002), which is considered to create favorable conditions for fungal growth. High humidity accompanied by lack of ventilation in storage rooms in Egyptian museums enhances the fungal growth on textile objects. In some cases contaminated conservation materials such as improper polymers can cause fungal infestation of conserved textile objects (Florian, 1997).

Fungal deterioration causes changes in the properties of textiles such as losses in the strength, their general durability, discoloration, and appearance. In addition, many fungi contain coloured substances that can cause stains and spots on textile objects. Fungal deterioration causes various coloured stains on the surface of a textile object (Mukerji et al., 1995; Abdel-Kareem, 2007). These stains contain chemical substances which can still deteriorate a textile object if the fungus dies or is killed (Montegut et al., 1991; Florian, 2004).

* Corresponding author: O. Abdel-Kareem, Conservation Department, Faculty of Archaeology, Cairo University, Egypt; e-mail: Omaa67@yahoo.com 
It is important to think of a way to remove these fungal stains from textile objects. However, it is reported that fungal stains are extremely difficult to remove from historical textile objects as the methods that are known for removing fungal stains are very harmful to textiles (Agrawal, 2001). The chemical changes occurring with the fungal growth result in decreased fabric strength and lead to partial or total destruction of the material (Szostak-Kotowa, 2004). Molds can be dangerous to people working in museums and in some cases can pose a major health hazard (Merritt, 1993). A large number of fungal species are reported to cause deterioration of textiles and culture heritage. There are different methods for prevention of fungal deterioration of textiles with the use of chemicals and nonchemical methods. Chemical treatments include using fungicides and fumigants. Nonchemical methods comprise the use of UV and gamma rays, heat, electron beams and microwaves (Bhatnagar and Mani, 2001). Unfortunately these methods are not evaluated well from conservation perspective. Most of the methods mentioned above may cause damage to ancient textiles such as fading of dyes, dryness of fibers, and breakdown in the strength of the textile fibers and so on.

It is emphasized that the best method to prevent fungal growth on museum textiles, is to protect textile surfaces from contamination, control moisture in materials and relative humidity to be low and avoid the treatments which may activate conidia to start germination (Florian, 1997). In some cases this method could not be applied in all museums (Abdel-Kareem, 2000a). In such a situation some other solutions have to be thought off, such as fumigants and fungicides for preservation of textiles. There are a large number of studies that have been carried out on fungicides used for protection of museum textiles (Agrawal, 1995; Abdel-Kareem, 2000a). Numerous studies for industrial purposes have also been carried out on the microbial deterioration and degradation of polymers and on their protection with biocides (Whitney, 1996; Srivastava, 2001; Lucas et al., 2008). Other papers have also focused on textile conservation methods (Abdel-Kareem, 2000b; 2005). In this study a new approach to prevent fungal growth on consolidated historical linen textiles was evaluated.

\section{Experimental}

\section{Material and Methods}

\section{Isolation and identification of fungi from historical} biodeteriorated textile samples

Biodeteriorated samples. Both cotton swab technique and biodeteriorated textile part technique were used for collecting samples for isolation of fungi from historical textile objects. Although it was confirmed in previous studies that using of parts of the investigated objects is the best method which can be used in identifying fungi from biodeteriorated historical textiles (Abdel-Kareem et al., 1997), in some cases this method is considered destructive. Thus it could not be used with all investigated textile objects in this study. Instead, the cotton swab technique was applied with all investigated textile objects. This method scores highly in most of the criteria required for isolating fungi from ancient objects (Chaisrisook et al., 1995).

Isolation and identification of fungi. Very small biodeteriorated textile parts separated from the original ancient object were washed with sterilized distilled water and were transferred by using sterilized tweezers and were put on 2 modified media in Petri dishes (Abdel-Kareem et al., 1997). The used media are 1 - Medium of Greathous, Klemme and Barker with disk of pure $100 \%$ linen fabric with linen textile samples or with disk of pure $100 \%$ wool fabric with wool textile samples. 2 - Czapek-Dox agar modified without sugar.

In the case of using the cotton swab technique the fungal species were isolated by using sterile moist cotton buds swabbed onto the surface of textile objects where fungal growth or fungal structures were observed. Cotton swabs were then used to distribute the fungi on media in Petri dishes. The Petri dishes were then incubated for three to four weeks at $28^{\circ} \mathrm{C}$ (until growth of colonies was observed). For purification and identification, the developed fungi were isolated in pure culture on slants of the appropriate media (Czapek dox agar and malt extract agar) (Booth, 1971). Identification of fungal species was performed according to standardized methods by consulting the appropriate manuals (Domsch et al., 1980; Gilman, 1975; Raper, and Fennell, 1965; Raper and Thom, 1949).

\section{Evaluating the suggested treatment for controlling fungal growth using consolidated polymers}

It was confirmed in previous studies that some polymers used in the conservation of historical textiles can accelerate fungal growth on historical textiles (Keyserlingk, 1990); some of them may inhibit fungal growth and others can accelerate it (Abdel-Kareem, $2000 \mathrm{~b} ; 2005)$. However, there is no doubt that all the polymers used in textile conservation cannot prevent the fungal deterioration of textiles. This study introduces a new suggestion by adding some selected fungicides that are commonly used in textile conservation to some selected polymers which are often used in textile conservation. For evaluating the new composed chemical the following processes were carried out.

Polymers. Four selected polymers were used in this study (see Table I). The polymers were selected 
Table I

List of polymers used in this study.

\begin{tabular}{|c|l|l|l|}
\hline \multicolumn{2}{|c|}{ Trade name } & \multicolumn{1}{|c|}{ Chemical name } & Producer \\
\hline 1 & Klucel G (SD) & Hydroxypropylcellulose & $\begin{array}{l}\text { Lascaux } \\
\text { Restauro }\end{array}$ \\
\hline 2 & Lascaux 498 HV (E) & $\begin{array}{l}\text { Butyl acrylate / } \\
\text { methyl methylacrylate }\end{array}$ & $\begin{array}{l}\text { Lascaux } \\
\text { Restauro }\end{array}$ \\
\hline 3 & Mowilith DM5 (E) & $\begin{array}{l}\text { Vinyl acetate/acrylic } \\
\text { ester copolymer }\end{array}$ & Hoechst \\
\hline 4 & Mowilith DMC2 (E) & $\begin{array}{l}\text { Vinyl acetate/dibutyle } \\
\text { maleate copolymer }\end{array}$ & Hoechst \\
\hline 5 & Tylose MH300 (SD) & $\begin{array}{l}\text { Methyl hydroxy } \\
\text { ethyl cellulose }\end{array}$ & Hoechst \\
\hline
\end{tabular}

Table II

List of fungicides used in this study.

\begin{tabular}{|c|c|l|c|}
\hline \multicolumn{2}{|c|}{ Trade name } & \multicolumn{1}{c|}{ Chemical name } & Producer \\
\hline 1 & Preventol O-Na & $\begin{array}{l}\text { Sodium o-phenyl-phenol } \\
\text { (NaOPP)/2-hydroxybiphenyl } \\
\text { sodium salt tetra hydrate }\end{array}$ & Bayer \\
\hline 2 & Neo-Desogen & $\begin{array}{l}\text { a water solution of ammonium } \\
\text { basic with a strong biocide action }\end{array}$ & ARTE \\
\hline
\end{tabular}

according to the relevant references that confirmed that these polymers are suitable, effective and commonly used in the reinforcement of textile artefacts (Abdel-Kareem, 2005; Abdel-Kareem et al., 2008).

Fungicides. Two selected fungicides were used in this study (Table II). The fungicides were selected according to the relevant references that confirmed that these fungicides are suitable and effective in treatment of textile artefacts against fungal deterioration (Abdel-Kareem and Radwan, 2004).

Preparation of samples. Unbleached linen fabric samples were cut into $10 \times 2 \mathrm{~cm}$ (length $\times$ width) warp test specimens. The warp strips were produced by raveling away yarns on each side forming $1.5 \mathrm{~cm}$ wide strips with a $2.5 \mathrm{~mm}$ fringe down each side. Five samples were used for each test.

Treatments. Linen textile samples were treated with the selected polymers by using impregnation method (Abdel-Kareem, 2005), with some modification in the technique by adding the tested fungicides to the solution. The Preventol was used in $1 \%$ concentration and Neo-Desogen was used in $2 \%$ concentration (Table III).

Fungal treatment of samples. Treated and untreated linen textile samples were exposed to attack by pure culture of Aspergillus niger, Chaetomium golobosum and Penicillium funiculosum by using an agar plate test. These fungal species are the most dominant ones isolated from ancient Egyptian textiles textile samples in this study. It was confirmed in previous studies that the selected three fungi are considered to play the greatest role in the decomposition of
Table III

The suggested treatment for controlling the fungal growth.

\begin{tabular}{|r|l|}
\hline \multicolumn{2}{|l|}{ Polymer } \\
\hline 0 & untreated \\
\hline 1 & Klucel G 4\% \\
\hline 2 & Klucel G 4\% + Neo-Desogen \\
\hline 3 & Klucel G 4\% + Preventol \\
\hline 4 & Lascaux 498 HV 10\% \\
\hline 5 & Lascaux 498 HV 10\% + Neo-Desogen \\
\hline 6 & Lascaux 498 HV 10\% + Preventol \\
\hline 7 & Mowilith $10 \%$ \\
\hline 8 & Mowilith $10 \%+$ Neo-Desogen \\
\hline 9 & Mowilith $10 \%+$ Preventol \\
\hline 10 & Tylose $4 \%$ \\
\hline 11 & Tylose $4 \%+$ Neo-Desogen \\
\hline 12 & Tylose $4 \%+$ Preventol \\
\hline
\end{tabular}

cellulosic materials of all fungi isolated from historical Egyptian textiles (Abdel-Kareem and Szostak-Kotowa, 2005; Garg and Dhawan, 2005). Also, these fungi are commonly used for evaluation of the resistance of polymers to fungal deterioration (Whitney, 1996). Petri dishes containing Czapek-Dox agar medium modified without sugar were used (Abdel-Kareem et al., 1997). The medium was inoculated with spore suspension (14-day old culture) of each one of the tested fungi. The spore suspension of the fungus was spread on the surface of the medium. The textile samples were put on the inoculated surface of medium. The plates were incubated at $28^{\circ} \mathrm{C}$. Fourteen days later, linen textile samples were picked out and washed with water to remove mycelium. They were then air dried in room conditions. Before testing, the specimens were conditioned at $20 \pm 2^{\circ} \mathrm{C}$ and $65 \% 2 \mathrm{RH}$.

\section{Evaluation methods}

All treated and untreated samples before and after fungal deterioration were investigated with tensile tester and colorimeter.

Tensile strength and elongation. Tensile strength and elongation of all samples before and after the fungal treatment were tested using a testing machine, type Zwick 1445 . These tests were done according to the ASTM (2000) D 5035-95. The initial distance of the jaws was $50 \mathrm{~mm}$ and the testing speed was $25 \mathrm{~mm} / \mathrm{min}$, temperature was $23^{\circ} \mathrm{C}$, and R.H.65\%. Five samples were used for each test and statistical data were calculated for all tested samples.

Colorimetric measurements. The colore values of all textile samples before and after deterioration by different fungi have been carried out with Optimacth 3100 color Spectrophotometer using the CIELab color system. The CIELab color coordinates for L (lightness), a (red/green axis), and b (yellow/blue 
axis) values were recorded. Color changes for all samples after the fungal treatment was calculated and expressed as $\Delta \mathrm{L}, \Delta \mathrm{a}, \Delta \mathrm{b}$. Calculation of total color change $(\Delta \mathrm{E})$ is achieved by the use of the following equations: $\Delta \mathrm{E}=\left[(\Delta \mathrm{L})^{2}+(\Delta \mathrm{a})^{2}+(\Delta \mathrm{b})^{2}\right]^{0.5}$.

\section{Results and Discussion}

\section{Isolation and identification of fungi}

Fungi isolated from various biodeteriorated textile fabrics from storage area in the Egyptian museum are shown in Table IV. The obtained results show that 207 isolates, representing 31 species of fungi were identified on samples obtained from the Egyptian museum. The most dominant fungi on linen textile fabrics are Aspergillus (15 species), Penicillium (10 species), Chaetomium (4 species), Alternaria (1 species), and

Table IV

Isolated fungi from tested bio-deteriorated linen samples from the Egyptian museum in Cairo.

\begin{tabular}{|c|c|c|}
\hline \multicolumn{2}{|r|}{ Fungi } & \multirow{2}{*}{\begin{tabular}{|c|c|}
$\begin{array}{c}\text { No } \\
\text { of isolations }\end{array}$ \\
8
\end{tabular}} \\
\hline 1 & Alternaria alternate (Fr.) Keissler & \\
\hline 2 & Aspergillus carbonarius Bainier & 6 \\
\hline 3 & Aspergillus chrysellus Kown \& Fennell & 3 \\
\hline 4 & Aspergillus fischeri Wehmer & 2 \\
\hline 5 & Aspergillus flavus Link & 12 \\
\hline 6 & Aspergillus flaschentraegeri Stolk & 2 \\
\hline 7 & Aspergillus fumigatus Fresenius & 15 \\
\hline 8 & Aspergillus nidulans Eidam & 9 \\
\hline 9 & Aspergillus niger Tieghem & 13 \\
\hline 10 & Aspergillus terrus Thom & 11 \\
\hline 11 & Aspergillus ustus Thom \& Church & 2 \\
\hline 12 & Aspergillus versicolor (vuill.) Tiraboschi & 4 \\
\hline 13 & Aspergillus sp. & 5 \\
\hline 14 & Aspergillus sp. & 4 \\
\hline 15 & Aspergillus sp. & 4 \\
\hline 16 & Chaetomium cochlioides Palliser & 11 \\
\hline 17 & Chaetomium globosum Kunze & 14 \\
\hline 18 & Chaetomium sp. & 7 \\
\hline 19 & Chaetomium sp. & 6 \\
\hline 20 & Penicillium asperum (Shear) n. comb. & 6 \\
\hline 21 & Penicillium citrinum Thom & 8 \\
\hline 22 & Penicillium chrysogenum Thom & 4 \\
\hline 23 & Aspergillus chrysellus Kown \& Fennell & 3 \\
\hline 24 & Penicillium cyclopium Westling & 6 \\
\hline 25 & Penicillium funiculosum Thom & 10 \\
\hline 26 & Penicillium soppi Zaleski & 6 \\
\hline 27 & Penicillium wortmanni Klöcker & 7 \\
\hline 28 & Penicillium sp. & 4 \\
\hline 29 & Penicillium sp. & 4 \\
\hline 30 & Penicillium sp. & 4 \\
\hline 31 & Trichoderma viride Pers. Ex Fr. & 7 \\
\hline
\end{tabular}

Table V

Isolated fungi from tested bio-deteriorated linen samples from the Coptic Museum Cairo.

\begin{tabular}{|c|c|c|}
\hline \multicolumn{2}{|r|}{ Fungi } & \multirow{2}{*}{\begin{tabular}{|c}
$\begin{array}{c}\text { No } \\
\text { of isolations }\end{array}$ \\
11 \\
\end{tabular}} \\
\hline 1 & Alternaria alternate (Fr.) Keissler & \\
\hline 2 & Alternaria tenuissima Kunze & 2 \\
\hline 3 & Aspergillus auratus Warcup & 2 \\
\hline 4 & Aspergillus carbonarius Bainier & 9 \\
\hline 5 & Aspergillus chrysellus Kown \& Fennell & 5 \\
\hline 6 & Aspergillus fischeri Wehmer & 4 \\
\hline 7 & Aspergillus flavus Link & 14 \\
\hline 8 & Aspergillus flaschentraegeri Stolk & 4 \\
\hline 9 & Aspergillus fumigatus Fresenius & 17 \\
\hline 10 & Aspergillus nidulans Eidam & 11 \\
\hline 11 & Aspergillus niger Tieghem & 14 \\
\hline 12 & Aspergillus proliferans Smith & 3 \\
\hline 13 & Aspergillus spinulosus Warcup & 3 \\
\hline 14 & Aspergillus terrus Thom & 12 \\
\hline 15 & Aspergillus ustus Thom \& Church & 4 \\
\hline 16 & Aspergillus versicolor (vuill.) Tiraboschi & 5 \\
\hline 17 & Aspergillus sp. & 4 \\
\hline 18 & Aspergillus sp. & 4 \\
\hline 19 & Aspergillus sp. & 4 \\
\hline 20 & Chaetomium cochlioides Palliser & 12 \\
\hline 21 & Chaetomium globosum Kunze & 13 \\
\hline 22 & Chaetomium sp. & 6 \\
\hline 23 & Chaetomium sp. & 7 \\
\hline 24 & Penicillium asperum (Shear) n.comb. & 8 \\
\hline 25 & Penicillium biforme Thom & 2 \\
\hline 26 & Penicillium citrinum Thom & 9 \\
\hline 27 & Penicillium chrysogenum Thom & 10 \\
\hline 28 & Aspergillus chrysellus Kown \& Fennell & 12 \\
\hline 29 & Penicillium cyclopium Westling & 8 \\
\hline 30 & Penicillium funiculosum Thom & 12 \\
\hline 31 & Penicillium raistrickii Smith & 2 \\
\hline 32 & Penicillium soppi Zaleski & 5 \\
\hline 33 & Penicillium wortmanni Klöcker & 9 \\
\hline 34 & Penicillium sp. & 6 \\
\hline 35 & Penicillium sp. & 5 \\
\hline 36 & Penicillium sp. & 3 \\
\hline 37 & Trichoderma viride Pers. Ex Fr. & 8 \\
\hline
\end{tabular}

Trichoderma (1 species). The order of the occurrence of fungi on linen textile fabrics is as follows: Aspergillus $>$ Penicillium $>$ Chaetomium $>$ Alternaria $>$ Trichoderma viride.

Fungi isolated from various biodeteriorated textile fabrics from a storage area in the Coptic museum are shown in Table V. The obtained results show that 269 isolates, representing 37 species of fungi were identified in samples obtained from the Egyptian museum. The most dominant fungi on linen textile fabrics are Aspergillus (18 species), Penicillium (12 species), Chaetomium (4 species), Alternaria (2 species), and Trichoderma (1 species). The order of the occurrence 
Table VI

Isolated fungi from tested bio-deteriorated wool samples from the Coptic Museum Cairo.

\begin{tabular}{|r|l|c|}
\hline \multicolumn{2}{|c|}{ Fungi } & $\begin{array}{c}\text { No } \\
\text { of isolations }\end{array}$ \\
\hline 1 & Alternaria alternate, & 5 \\
\hline 2 & Aspergillus cervinus Neill & 3 \\
\hline 3 & Aspergillus flavus Link & 4 \\
\hline 4 & Aspergillus fischeri Wehmer & 3 \\
\hline 5 & Aspergillus fumigatus Fresenius & 8 \\
\hline 6 & Aspergillus nidulans Stolk & 3 \\
\hline 7 & Aspergillus niger Tieghem & 7 \\
\hline 8 & Aspergillus raperi Stolk & 2 \\
\hline 9 & Aspergillus sparsus Raper \& Thom & 2 \\
\hline 10 & Aspergillus spinulosus Warcup & 5 \\
\hline 11 & Aspergillus wentii Wehmer & 2 \\
\hline 12 & Aspergillus sp. & 2 \\
\hline 13 & Aspergillus sp. & 2 \\
\hline 14 & Penicillium canescens Sopp & 2 \\
\hline 15 & Penicillium cyclopium Westling & 3 \\
\hline 16 & Penicillium granulatum Bainier & 2 \\
\hline 17 & Penicillium lanoso viride Thom & 6 \\
\hline 18 & Penicillium paxilli Bainier & 6 \\
\hline 19 & Penicillium soppi Zaleski & 2 \\
\hline 20 & Penicillium sp. & 4 \\
\hline 21 & Penicillium sp. & \\
\hline 22 & Chaetomium globosum Kunze & 2 \\
\hline
\end{tabular}

of fungi on linen textile fabrics is as follows: Aspergillus $>$ Penicillium $>$ Chaetomium $>$ Alternaria $>$ Trichoderma viride.

Fungi isolated from various biodeteriorated wool textile fabrics from storage area in the Coptic museum are presented in Table VI. The obtained results show that 77 isolates, representing 22 species of fungi, were identified on samples obtained from the Egyptian museum. The most dominant fungi on wool textile fabrics are Aspergillus (12 species), Penicillium (8 species), Alternaria (1 species), and Chaetomium (1 species). The order of the occurrence of fungi on wool textile fabrics is as follows: Aspergillus $>$ Penicillium $>$ Chaetomium $>$ Alternaria.

The results showed that about 37 fungal species were isolated and identified on linen textiles from both investigated museums. Most of the identified fungi in the current study were isolated from other Egyptian textile objects in a previous study by AbdelKareem et al. (1997) who isolated and identified about 30 fungal species from ancient linen textiles. The results confirm that the textile samples in the current study are more deteriorated by fungi than in a previous study by Abdel-Kareem et al. (1997). It is should noticed that about 7 more fungal species were isolated in this study than in the previous one. This may be due to the fact that the examined samples were col- lected from storage rooms while the investigated samples in the previous study were collected from display showcases and excavations. This result indicates that the textiles in storage rooms in Egyptian museums suffer from fungal deterioration problem more than the textile collections in display areas. Also the results show that linen textiles are more infested by fungi than wool textiles as the number of identified fungi on linen is greater than on wool.

The number of isolated fungi from both investigated museums included in the research shows that their collections suffer from excessive fungal infestation. This is due to the fact that both museums use improper storage methods. The results show that the textile collection in the storage rooms at the Coptic museum are infested by fungi more than the textile collection in the storage rooms at the Egyptian $\mathrm{Mu}-$ seum. This may due to that most of the textiles in the Egyptian Museum were excavated from dry tombs, while most of the textiles in the Coptic Museum were collected from churches or tombs in bad condition more than ancient Egyptian tombs. This may also be due to the environmental conditions in the storage area in both the Coptic Museum and the Egyptian Museum. However, the results show that the linen textile fabrics in the Coptic Museum are more liable to fungal deterioration than wool textile fabrics (see Tables V, VI). These results are in agreement with the results obtained by Abdel-Kareem et al., who confirmed that all types of ancient textile fibres are liable to fungal attack; cellulosic fibres are more liable to fungal attack than animal fibres (Abdel-Kareem et al., 1997).

The results show that most of identified fungi belong to the subdivision Deuteromycetes class or Fungi Imperfect. These fungi are called conidial fungi because their growth is initiated by conidia (Florian, 2004). These fungi are capable of rapid growth when the environmental conditions are favorable and are also able to survive under unfavorable conditions (Aranyanak, 1995). Most of identified fungal species were reported in previous studies to cause deterioration of textiles. Many authors consider that most of these fungal species are the most active fungi among all fungal genera identified on textiles in the degradation of historical textiles (Montegut et al., 1991; AbdelKareem et al., 1997; Agrawal, 2001, Bhatnagar and Mani, 2001; Grag and Dhawan, 2005). Most of identified fungi were reported that they contribute to discolouration of textiles (Aranyanak, 2005; AbdelKareem and Szostak-Kotowa, 2005; Abdel-Kareem, 2007). The results showed that the most dominant fungi on the investigated textile samples belong to Aspergillus and Penicillium. These two genera are very important, since they include species that can grow at relatively much lower conditions of moisture availability than other cellulolytic fungi. Under poor 
Table VII

The tensile strength for the samples after treated with fungi.

\begin{tabular}{|c|c|c|c|c|c|c|c|c|}
\hline \multirow{2}{*}{ Polymer } & \multicolumn{2}{|c|}{ Control } & \multicolumn{2}{c|}{ Aspergillus } & \multicolumn{2}{c|}{ Chaetomium } & \multicolumn{2}{c|}{ Penicillium } \\
\cline { 2 - 9 } & $\mathrm{N} / \mathrm{mm}^{2}$ & S.D. & $\mathrm{N} / \mathrm{mm}^{2}$ & S.D. & $\mathrm{N} / \mathrm{mm}^{2}$ & S.D. & $\mathrm{N} / \mathrm{mm}^{2}$ & S.D. \\
\hline 0 & 34.35 & 0.94 & 4.02 & 0.70 & 4.24 & 1.22 & 5.98 & 1.12 \\
\hline 1 & 36.30 & 1.13 & 11.30 & 1.09 & 13.48 & 1.27 & 15.00 & 1.41 \\
\hline 2 & 36.41 & 0.94 & 33.04 & 1.36 & 33.48 & 0.94 & 34.46 & 1.22 \\
\hline 3 & 36.74 & 0.81 & 28.59 & 1.05 & 35.11 & 1.25 & 31.63 & 1.10 \\
\hline 4 & 37.50 & 1.37 & 19.02 & 0.89 & 19.89 & 1.22 & 20.87 & 1.24 \\
\hline 5 & 37.39 & 1.30 & 31.52 & 0.99 & 30.87 & 1.08 & 35.43 & 1.07 \\
\hline 6 & 37.28 & 0.96 & 31.20 & 1.43 & 33.04 & 0.82 & 32.50 & 1.30 \\
\hline 7 & 37.07 & 1.33 & 16.63 & 1.16 & 17.50 & 1.34 & 21.74 & 1.28 \\
\hline 8 & 37.28 & 0.85 & 34.02 & 1.26 & 33.26 & 1.24 & 34.35 & 1.35 \\
\hline 9 & 37.50 & 1.07 & 33.59 & 1.25 & 34.78 & 1.17 & 36.09 & 1.21 \\
\hline 10 & 38.15 & 0.93 & 14.59 & 1.39 & 15.65 & 1.17 & 17.83 & 1.16 \\
\hline 11 & 38.26 & 1.02 & 31.96 & 1.28 & 34.02 & 1.40 & 32.28 & 1.41 \\
\hline 12 & 38.37 & 1.27 & 26.41 & 1.14 & 30.11 & 1.12 & 33.15 & 1.29 \\
\hline
\end{tabular}

Table VIII

The elongation for the samples after treated with fungi.

\begin{tabular}{|c|c|c|c|c|c|c|c|c|}
\hline \multirow{2}{*}{ Polymer } & \multicolumn{2}{|c|}{ Control } & \multicolumn{2}{c|}{ Aspergillus } & \multicolumn{2}{c|}{ Chaetomium } & \multicolumn{2}{c|}{ Penicillium } \\
\cline { 2 - 9 } & F max\% & S.D. & F max\% & S.D. & F max\% & S.D. & F max\% & S.D. \\
\hline 0 & 18.00 & 0.55 & 6.00 & 0.89 & 8.00 & 0.63 & 8.00 & 0.89 \\
\hline 1 & 20.00 & 0.84 & 9.00 & 1.41 & 10.00 & 1.10 & 10.00 & 1.26 \\
\hline 2 & 20.00 & 1.26 & 16.00 & 1.26 & 16.00 & 1.26 & 16.00 & 1.10 \\
\hline 3 & 20.00 & 1.41 & 16.00 & 0.63 & 16.00 & 0.63 & 16.00 & 0.63 \\
\hline 4 & 18.00 & 1.10 & 8.00 & 0.89 & 9.00 & 1.41 & 9.00 & 1.10 \\
\hline 5 & 18.00 & 1.41 & 16.00 & 1.10 & 16.00 & 1.90 & 16.00 & 1.26 \\
\hline 6 & 18.00 & 0.63 & 16.00 & 0.63 & 16.00 & 0.89 & 16.00 & 0.63 \\
\hline 7 & 22.00 & 0.89 & 9.00 & 1.10 & 10.00 & 0.89 & 9.00 & 1.41 \\
\hline 8 & 22.00 & 0.89 & 16.00 & 1.10 & 16.00 & 1.26 & 16.00 & 1.26 \\
\hline 9 & 22.00 & 1.10 & 16.00 & 0.63 & 16.00 & 0.63 & 16.00 & 0.63 \\
\hline 10 & 20.00 & 0.63 & 8.00 & 0.63 & 9.00 & 1.41 & 10.00 & 1.41 \\
\hline 11 & 20.00 & 1.10 & 16.00 & 1.26 & 16.00 & 1.26 & 16.00 & 1.41 \\
\hline 12 & 20.00 & 1.26 & 16.00 & 1.10 & 16.00 & 1.10 & 16.00 & 1.10 \\
\hline
\end{tabular}

storage conditions, the water that such less demanding species produce as a result of their metabolism can accumulate, raising the moisture status of materials to levels at which more highly degradable species may flourish (Szostak-Kotowa, 2004).

For all previous causes there is a need to decontaminate the biodeteriorated textile objects from conidia and mycelium in order to reduce the fungal growth on these textile objects and prevent the contamination of other objects. For that the surface of the biodeteriorated textile objects should be vacuumed cleaned to remove mycelium and conidia. The vacuum cleaning method chosen should be acceptable by conservation standards to protect the integrity of the textile object. The main goal of this process is to reduce the fungal load to the minimal level of the infestation and prevent recontamination (Florian, 2004). A vacuum cleaning method should be applied at low suction power, and through a gauze sheet or fin netting fabric placed over the textile object in order to not disturb loose fibers (Museums \& Galleries Commission, 1998). After decontaminating the biodeteriorated textile objects from conidia and mycelium the textile objects should be treated against fungal deterioration.

\section{Evaluating the suggested polymers}

Evaluation of the suggested polymers combined with fungicides was carried out based on the obtained results from the changes in the tensile strength and the colour values of treated and untreated linen samples after the fungal treatments.

Tensile strength and elongation. The results of tensile strength and the elongation of the control samples and the biodeteriorated samples are blotted in Table VII and VIII. The loss percent (\%) in the 


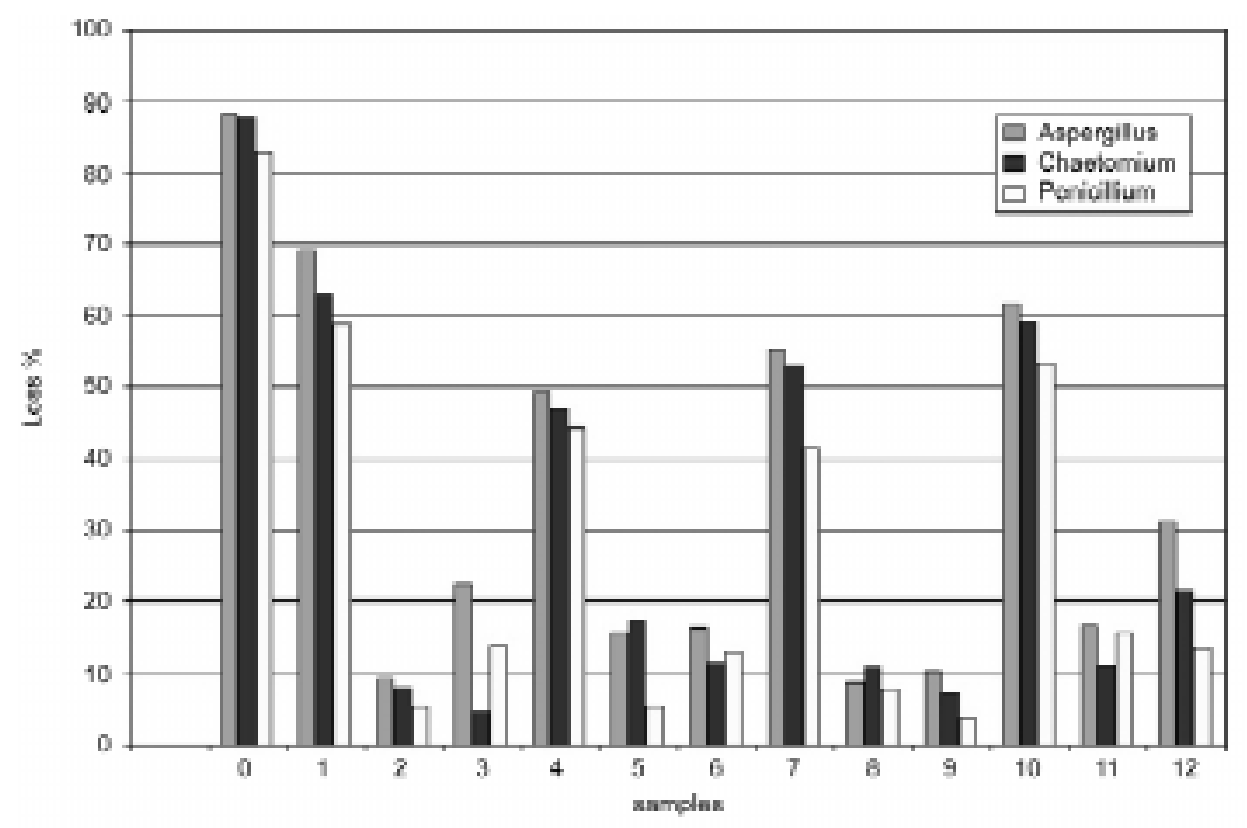

Fig. 1. The loss $\%$ in the tensile strength of the sampes after the fungal treatment.

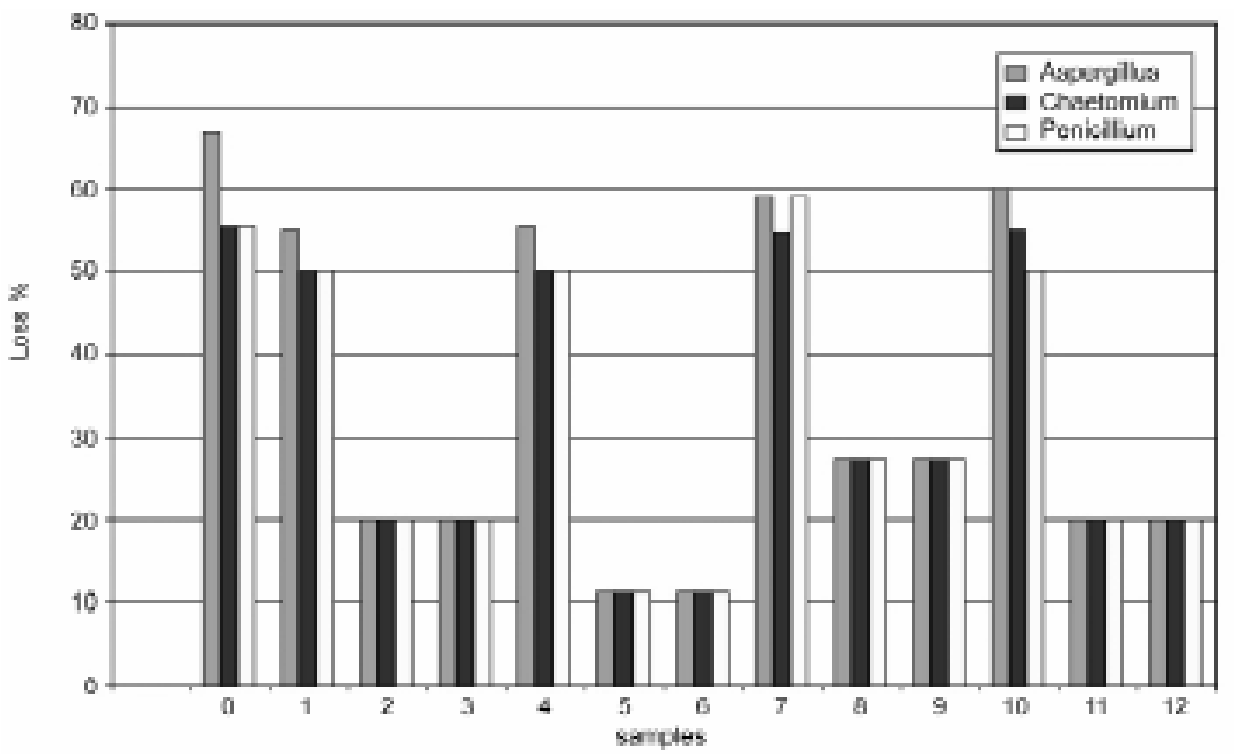

Fig. 2. The loss $\%$ in the elongation of the sampes after the fungal treatment.

tensile strength and the elongation of treated and untreated linen samples after fungal incubations are shown in figures 1 and 2. Tensile strength measurements showed that there were considerable differences in tensile strength and elongation between unconsolidated linen samples, linen samples treated with polymers only and linen samples treated with polymers contained different fungicides. The results showed that all tested polymers without fungicides contains have reduce the fungal deterioration of linen samples but not prevent the fungal deterioration completely. These results are in agreement with the results obtained by Abdel-Kareem (2000b). The results in figures 1, 2, show that the least changes in the tensile strength of all tested samples after the fungal treatment were on samples treated with Klucel G + Neo-Desogen. This result confirms that Klucel G + Neo-Desogen is the most effective treatment among all tested treatments that can control the fungal deterioration of linen textiles by all tested fungi. Also the results show that Neo-Desogen is the best fungicides among all tested fungicides can be added to all tested polymers for protection of linen textiles against fungal deterioration.

Colorimetric measurements. The changes in the colour values of treated and untreated linen samples after fungal incubations by Aspergillus are shown in Table IX. The changes in the colour values of treated and untreated linen samples after fungal incubations 
Table IX

The changes in the color values for the samples after the fungal treatment with Aspergillus.

\begin{tabular}{|c|r|r|r|r|}
\hline Polymer & \multicolumn{1}{|c|}{$\mathrm{dL}$} & $\mathrm{da}$ & \multicolumn{1}{c|}{$\mathrm{db}$} & \multicolumn{1}{c|}{$\mathrm{dE}$} \\
\hline 0 & -24.57 & 0.96 & 2.92 & 24.76 \\
\hline 1 & -5.82 & 0.56 & 0.78 & 5.90 \\
\hline 2 & 0.77 & 0.37 & -0.44 & 0.96 \\
\hline 3 & -1.86 & 0.25 & -0.29 & 1.90 \\
\hline 4 & -9.12 & -0.19 & -0.31 & 9.13 \\
\hline 5 & -1.24 & 0.05 & 0.06 & 1.24 \\
\hline 6 & -0.75 & 0.22 & -0.55 & 0.96 \\
\hline 7 & -9.84 & 0.4 & -1 & 9.90 \\
\hline 8 & -2.06 & 0.94 & 0.83 & 2.41 \\
\hline 9 & -2.02 & 0.65 & 0.16 & 2.13 \\
\hline 10 & -10.38 & 0.55 & -1.04 & 10.45 \\
\hline 11 & -1.69 & 0.44 & -0.78 & 1.91 \\
\hline 12 & -1.28 & 0.51 & 0.37 & 1.43 \\
\hline
\end{tabular}

Table X

The changes in the color values for the samples after the fungal treatment with Chaetomium.

\begin{tabular}{|c|r|r|r|r|}
\hline Polymer & \multicolumn{1}{|c|}{$\mathrm{dL}$} & \multicolumn{1}{c|}{$\mathrm{da}$} & \multicolumn{1}{c|}{$\mathrm{db}$} & \multicolumn{1}{c|}{$\mathrm{dE}$} \\
\hline 0 & -26.39 & 1.51 & 3.13 & 26.62 \\
\hline 1 & -5.35 & 0.12 & 0.6 & 5.38 \\
\hline 2 & -0.55 & 0.7 & 0.04 & 0.89 \\
\hline 3 & -1.81 & 0.63 & -0.38 & 1.95 \\
\hline 4 & -9.39 & 0.19 & 4.25 & 10.31 \\
\hline 5 & -1.64 & 0.12 & 0.62 & 1.76 \\
\hline 6 & -1.41 & 0.6 & -0.26 & 1.55 \\
\hline 7 & -5.36 & 1.18 & 3.19 & 6.35 \\
\hline 8 & -1.02 & 0.5 & 0.19 & 1.15 \\
\hline 9 & -1.49 & 0.64 & 0.19 & 1.63 \\
\hline 10 & -7.97 & 0.54 & 1.35 & 8.10 \\
\hline 11 & -0.29 & 0.35 & -0.52 & 0.69 \\
\hline 12 & -1.81 & 0.47 & -0.53 & 1.94 \\
\hline
\end{tabular}

by Chaetomium are shown in Table X. Also the changes in the colour values of treated and untreated linen samples after fungal incubations by Pencillium are shown in Table XI. Colorimetric measurements showed that there were considerable differences in colour values unconsolidated linen samples, linen samples treated with polymers only and linen samples treated with polymers contained different fungicides. The results showed that all tested polymers without fungicides contains have reduced the fungal deterioration of linen samples but not prevent the fungal deterioration completely. These results are in agreement with the results obtained by Abdel-Kareem (2005), who confirmed that polymers reduce the fungal deterioration of linen samples but not prevent the fungal deterioration completely. The results showed that all tested polymers contained fungicides prevent the fungal deterioration of linen samples completely.
TTable XI

The changes in the color values for the samples after the fungal treatment with Pencillium.

\begin{tabular}{|c|r|r|r|r|}
\hline Polymer & \multicolumn{1}{|c|}{$\mathrm{dL}$} & $\mathrm{da}$ & $\mathrm{db}$ & $\mathrm{dE}$ \\
\hline 0 & -22.57 & 1.22 & 2.48 & 22.74 \\
\hline 1 & -5.07 & 0.05 & 4.71 & 6.92 \\
\hline 2 & -0.3 & 0.37 & 0.19 & 0.51 \\
\hline 3 & -1.41 & 0.64 & -0.45 & 1.61 \\
\hline 4 & -7.68 & -0.09 & 3.37 & 8.39 \\
\hline 5 & -1.03 & 0.04 & 0.66 & 1.22 \\
\hline 6 & -1.37 & 0.29 & 0.05 & 1.40 \\
\hline 7 & -10.77 & 0.13 & 4.73 & 11.76 \\
\hline 8 & -2.02 & 0.67 & 0.31 & 2.15 \\
\hline 9 & -0.3 & 0.57 & -0.06 & 0.65 \\
\hline 10 & -5.3 & 0.32 & 3.36 & 6.28 \\
\hline 11 & -1.46 & 0.85 & -0.68 & 1.82 \\
\hline 12 & -1.54 & 0.05 & 0.34 & 1.58 \\
\hline
\end{tabular}

\section{Suggested guidelines for controlling and prevention of the fungal deterioration on the textile collections in storage rooms of the studied museums}

Prevention includes protecting the textile objects from the contamination by fungi and controlling the environment conditions in storage rooms to prevent the development and the growth of fungi (Florian, 1997; Florian, 2004). One of the best methods for protection of textile objects from fungal infestations in museums, can be achieved by controlling the environmental conditions surrounding textile objects (Abdel-Kareem and Morsy, 2004). The following measures should be undertaken: Elimination/prevention of airborne fungi using the considerations mentioned by (Florian, 2004), for example use of protective dust covers for textile objects in storage area. Cleaning dust covers regularly. Performing regular maintenance of storage areas. Environmental conditions should be controllable within the storage storerooms. Temperature should be $18-22^{\circ} \mathrm{C}$ and relative humidity (RH) $45-55 \%$. This can be achieved by build new storerooms with air conditioning system. Also it is necessary to control in the RH in storerooms using suitable buffer materials such as silica gel. Repairing leaking ceiling in storage area. Placing portable ventilators in the storerooms. Setting a suitable fumigant in storerooms to reduce the chance of microorganisms growing on the collections in the museum.

Conclusion. There are obvious excessive fungal infestations in all tested textile objects in storage areas in both the Coptic Museum and the Egyptian Museum. The textile collection in the storage rooms in the Coptic museum is infested by fungi more than the textile collection in the storage room in the Egyptian Museum. The most dominant fungi isolated from 
tested samples belong to Aspergillus, Penicillium, Chaetomium, Alternaria and Trichoderma species. The order of occurrence of fungi on linen textile fabrics is as follows: Aspergillus $>$ Chaetomium $>$ Penicillium $>$ Alternaria $>$ Trichoderma viride. The order of occurrence of fungi on wool textile fabrics is as follows: Aspergillus $>$ Penicillium $>$ Chaetomium $>$ Alternaria. There is a necessity for using fungicides to be used for disinfection of the biodeteriorated textiles in both the Coptic Museum and the Egyptian Museum. In the cases where it is necessary to use polymers in the conservation of textile objects, the tested polymers containing one of the tested fungicides are very effective in preventing the fungal deterioration of textiles. Klucel G + Neo-Desogen is the most effective treatment among all tested treatments that can control the fungal deterioration of linen textiles by all the tested fungi. Neo-Desogen is the best fungicide among all the tested fungicides and can be added to all tested polymers for protection of linen textiles against fungal deterioration. This study should followed with another study to evaluate the long term effect of the tested polymers supplemented with fungicides on the properties of dyed and not dyed textiles.

\section{Literature}

Abdel-Kareem O. 2000a. Application of fungicides in preservation of ancient Egyptian linen textiles (in Polish). Czasopismo Techniczne 1A/2000: 189-201.

Abdel-Kareem O.2000b. Microbiological studies to evaluate polymers and resins used in consolidation of ancient Egyptian linen textiles (in Polish), Czasopismo Techniczne 1A/2000: 202-211.

Abdel-Kareem 0. 2002. The Guid in Treatment Conservation of Ancient Textiles, Cairo.

Abdel-Kareem O. 2005. The long-term effect of selected conservation materials used in treatment of museum artefacts on some properties of textiles. Polymer Degradation and Stability 87: 121-130. Abdel-Kareem 0. 2007. Effect of selected natural dyes in reduction of colour changes of Egyptian linen textiles by fungi. Annali di Chimica 9, 527-540.

Abdel-Kareem O. and O. Morsy. 2004. The effect of accelerated ageing on properties of Egyptian cotton textiles treated with Fungicides. First Annual Conference 13-15 July 2004, Scientific Analysis of Ancient and Historic Textiles: Informing Preservation, Display and Interpretation, Textile Conservation Centre, Winchester, U.K., pp. 57-65.

Abdel-Kareem O. and S. Radwan. 2004. Investigate the effect of fungi on properties of egyptian cotton textiles and their prevention with fungicides. Abstracts of ICOM Interim Meeting, Textiles, Leather and Related Materials, Legal Issues, Athens.

Abdel-Kareem O. and J. Szostak-Kot. 2005. Spectrophotometric studies of the effect of fungi on Egyptian linen textiles. Proceedings of the $4^{\text {th }}$ International Conference on Biodeterioration of Cultural Property, published by ICBCP, Lucknow, India. pp. 19-39.

Abdel-Kareem O., J. Szostak-Kot, W. Barabasz, I. Paśmionka and A. Galus. 1997. Fungal biodeterioration of ancient Egyptian textiles, part I: Surviving study for the most dominant fungi on ancient Egyptian textiles (in Polish). Drobnoustroje w środowisku występowanie, aktywność i znaczenie, Wyd. AR Kraków, 1997, pp. 279-290.

Abdel-Kareem O., Y. Zidan, N. Lokma and H. Ahmed. 2008. Conservation of a rare painted ancient Egyptian textile object from the Egyptian Museum in Cairo, e-PRESERVATION Science Journal: 9-16.

Agrawal O.P. 2001. Problems of biodeterioration of culture property in India. Studies in biodeterioration of materials 1, editors O.P. Agrawal, S. Dhawan, R. Pathak, INTACH, Lucknow, India, 2001. pp. ix-xii.

Agrawal. S.C. 1995. Biodeterioration of wool: Efficacy of some fungicides in controlling the deterioration. Proceedings of the $3^{r d}$ International Conference on Biodeterioration of Cultural Property, 1995, Bangkok, Thailand, edited by C. Aranyanak and C. Singhasiri, Thailand. pp. 202-209.

Aranyank C. 1995. Microscopical study of fungal growth on paper and textiles. Proceedings of the $3^{\text {rd }}$ International Conference on Biodeterioration of Cultural Property, 1995, Bangkok, Thailand, edited by C. Aranyanak and C. Singhasiri, Thailand, pp. 83-102. Aranyank C. 2005. Fungal stains on paper. Proceedings of the $4^{\text {th }}$ International Conference on Biodeterioration of Cultural Property, published by ICBCP, Lucknow, India. pp. 40-50.

ASTM. 2000. Standared test method for breaking force and elongation of textile fabrics (Strip Method), D 5035-95. Annual Book of ASTM Standards, USA, Vol 07.02, pp.682-688.

Bhatnagar I.K. and M. Mani. 2001. Requisites of an effective fungicide for works of art. Studies in Biodeterioration of Materials 1, editors O.P. Agrawal, S. Dhawan, R. Pathak, INTACH, Lucknow, India. pp. 89-96.

Booth C. 1971. Methods in Microbiology Vol. 4, Academic Press, London.

Chaisrisook C., P. Suwannarit and C. Aranyanak. 1995. Fungal deterioration of paper in the National Libraries and of Wooden objects in the National Museums, Bangkok, Thailand. Proceedings of the $3^{\text {rd }}$ International Conference on Biodeterioration of Cultural Property, July 4-7, 1995, Bangkok, Thailand, edited by C. Aranyanak, and C. Singhasiri, Thailand. pp. 665-674.

Domsch K.H., W. Gams and T.H. Anderson. 1980. Compendium of soil fungi, Vol. 1 and 2, Academic Press, London.

Florian M.L. 1997. Heritage Eaters, Insects \& Fungi in Heritage Collections, London. pp.111-153.

Florian M.L. 2004. Fungal Facts, Solving Fungal Problims in Heritage Collections, Archetype Publication Ltd, London, 2004. Garg K.L., and S. Dhawan, 2005. Efficacy of homoeopathic drugs for the control of fungal growth on cellulosic materials. Proceedings of the $4^{\text {th }}$ International Conference on Biodeterioration of Cultural Property, published by ICBCP, Lucknow, India. pp. 185-201. Gilman J.C. 1975. A Manual of Soil Fungi, Second Edition, USA, 1975.

Keyserlingk M.A. 1990. The use of adhesives in textile conservation. Preprints of the $9^{\text {th }}$ Triennial Meeting of the ICOM Committee for Conservation, Dresden, Germany. pp. 307-312.

Lucas N., C. Bienaime, C. Belloy, M. Queneudec, F. Silvestre, and J.E. Nava-Saucedo. 2008. Polymer biodegradation: Mechanisms and estimation techniques. Chemosphere 73 (2008): 429-442. Merritt J. 1993. Causes, Detection and Prevention of Mold and Mildew on Textiles. Conserve O Gram, Number 16/1, July 1993. Montegut D., N. Indictor and R.J. Kostler. 1991. Fungal deterioration of cellulosic textiles: a Review. International Biodeterioration Bulletin, 28, 209-226.

Mukerji K. G., K.L. Garg, and A.K. Mishra, 1995. Fungi in deterioration of museum objects. Proceedings of the $3^{\text {rd }}$ International Conference on Biodeterioration of Cultural Property, July 4-7, 1995, Bangkok, Thailand, edited by C. Aranyanak and C. Singhasiri, Thailand. pp. 226-241. 
Museums \& Galleries Commission. 1998. Standards in the Museum Care of Costume and Textile Collections, Museums \& Galleries Commission, UK.

Raper K.B. and D.I. Fennell. 1965. The Genus Aspergillus. The Williams \& Wilkins Co., Baltimor.

Raper K.B. and C. Thom. 1949. A Manual of the Penicillium. The Williams \& Wilkins Co., Baltimore.

Srivastava A.P., K. Narain and R.B. Srivastava. 2001

Biodeterioration of coated textile fabric and protective measures.
Studies in Biodeterioration of Materials 1, editors O.P. Agrawal, S. Dhawan, R. Pathak, INTACH, Lucknow, India. pp. 1-11.

Szostak-Kot J. 2004. Biodeteration of textiles, International Biodeterioration and Biodegradation 53: 165-170.

Whitney P.J. 1996. A comparison of two methods for testing defined formulations of PVC for resistance to fungal colonisation with two methods for theaAssessment of their biodegradation. International Biodeterioration and Biodegradation, 37, 205-213. 